\title{
Analysis of Particulate Organic Matter in Holocene Sediments of Coastal Plain from Pero Beach, Cabo Frio, Rio de Janeiro, Brazil
}

\author{
Taísa Camila Silveira de Souza, $2 *$, Marcelo de Araujo Carvalho ${ }^{2}$, Fabio Ferreira Dias ${ }^{3}$, Cíntia Ferreira \\ Barreto $^{4}$, Alex da Silva De Freitas ${ }^{4}$ AND JoÃo WAgner de AlenCar Castro 5
}

1 Programa de Pós-Graduação do Instituto de Geociências da Universidade Federal do Rio de Janeiro, Av. Athos da Silveira Ramos, 274 bloco G, 21.941-916, Cidade Universitária (Ilha do Fundão), Rio de Janeiro, RJ, Brazil. taisa_84@hotmail.com

2 Laboratório de Paleoecologia Vegetal, Departamento de Geociências do Museu Nacional/ UFRJ. Av. D. Pedro II s/nº - Quinta da Boa Vista, 20940040, São Cristóvão, Rio de Janeiro, RJ, Brazil. mcarvalho@mn.ufrj.br

3 Departamento de Análise Geoambiental, Universidade Federal Fluminense, Avenida Litorânea s/n, 24210-340 Niterói, RJ, Brazil. fabiofgeo@yahoo.com.br

4 Programa de Pós Graduação em Dinâmica dos Oceanos e da Terra, Universidade Federal Fluminense, Instituto de Geociências, Departamento de Geologia, 24210 -346, Niterói, Rio de Janeiro, RJ, Brazil. cintiapalino@yahoo.com.br; alexsilfre@gmail.com

5 Laboratório de Geologia Costeira, Sedimentologia e Meio Ambiente, Departamento de Geociências do Museu Nacional/ UFRJ. Av. D. Pedro II s/n ${ }^{\circ}$ - Quinta da Boa Vista, 20940-040, São Cristóvão, Rio de Janeiro, RJ, Brazil. castro@mn.ufrj.br

*CORRESPONDING AUTHOR, taisa_84@hotmail.com

Received on 3 Fevruary 2016

Received in revised form on 25 April 2016

Accepted on 1 June 2016

Editor:

Maria Virginia Alves Martins, Universidade do Estado do Rio de Janeiro, Brazil

\section{Abstract}

The study of palynofacies along a core drilled on the coastal plain of Cabo Frio, State of Rio de Janeiro, was carried out in order to contribute to the knowledge of the paleoenvironmental evolution of the Pero Beach region. The ages obtained from ${ }^{14} \mathrm{C}$ datings allowed to verify that the studied core records the past $6761 \pm 130 \mathrm{yrs}$ cal BP. Thirty samples were prepared by standard methodology for palynofacies. About three hundred particles of the particulate organic material was classified and recorded for each sample. Statistical methods were employed for the associations of particulate organic matter (R-mode cluster analysis) and levels (samples; Q-mode cluster analysis) analyzed along the core. Furthermore, the ratio Phytoclast Total Organic Carbon (Phy-TOC) was used to verify the

\section{Introduction}

The study of particulate organic matter in sediments at coastal areas has been widely used for the recognition of sedimentary evolutionary history of the coastline in different
Citation:

Souza, T.C.S., Carvalho, M.A., Dias, F.F., Barreto, C.F., Freitas, A.S., Castro, J.V.A., 2016. Analysis of particulate organic matter in Holocene sediments of coastal plain from Pero Beach, Cabo Frio, Rio de Janeiro, Brazil. Journal of Sedimentary Environments, 1(2): 242-253.

proximity of the source area. The three major groups of particulate organic matter found along the studied core are Phytoclasts, Amorphous Organic Matter (AOM) and Palynomorphs. The samples showed in general, a predominance of phytoclasts $(73.2 \%)$, followed by AOM $(18.6 \%)$ and Palynomorphs (8.2\%). Supported by statistical analysis, it was possible to deduce that the study area evolved since the middle Holocene from a marine environment to a paleolagoon.

Keywords: Palynofacies. Paleoenvironmental reconstruction. Holocene. Coastal region.

regions of Brazil (Zocatelli et al., 2012; Amaral et al., 2012; Hermany et al., 2013; Lorente et al., 2014; Gadens-Marcon et al., 2014a, b). According to Tyson (1995), the study of 
organic matter in sediments and rocks provides important information about palaeoenvironments as well as about displacement, maturity, source area of organic matter detachment. Thus, the use of technical qualification and quantification of particulate organic matter (palynofacies) is a good method to determine the magnitude and location of terrigenous deposits in proximal and distal areas. Results of this method provides information leading to the recognition of regressive and transgressive events associated with geological processes related to eustatic sea level (Traverse, 1994; Meyer et al., 2005; Lorente et al., 2014).

Transgressive and regressive events can be observed from palynological markers (e.g., dinoflagellate cysts, pollen and spores) and palynofacies. Sea level fluctuations can be deduced from the sedimentary record of sets of palynomorphs and particulate organic matter of terrigenous and marine origin (Meyer et al., 2005; Traverse, 2008; Amaral et al., 2012).

However, few works in Brazil used the study of palynofacies to reconstruct the Quaternary paleoenvironmental evolution in coastal environments (Medeanic and Silva, 2010; Meyer et al., 2010; Lorente et al., 2014). Thus, the main objective of this work is to contribute to the knowledge of the Holocene evolution of North Fluminense coastal plain. It was based on the analysis of the amount of continental and marine sedimentary organic material along a sedimentary core (with $2.50 \mathrm{~m}$ ) collected in Pero Beach, Cabo Frio, Rio de Janeiro, Brazil.

\section{Study area}

The Pero dune field is located at the city of Cabo Frio, north of the State of Rio de Janeiro. The Pero Beach with approximately $6.0 \mathrm{~km}$ long and NE-SW orientation is located between the latitudes $22^{\circ} 49^{\prime} \mathrm{S}$ and $22^{\circ} 52$ 'S and longitudes $41^{\circ} 58^{\prime} \mathrm{W}$ and $41^{\circ} 59^{\prime} \mathrm{W}$ (Fig. 1).

The region is composed of sandy beaches, marshes, infilled lagoons and oblique dune fields. According to Dourado and Silva (2005) and Fernandez and Rocha (2015), the region of Pero Beach is formed by a sandy spit with a maximum width of 1300 meters and an arc of beach with about 4800 meters long and NE-SW orientation. The area has a range of about 600 meters between the crest of the beach and dune area with underbrush. After this zone there is an exposed area with notorious wind movement which is partially colonized by salt marsh vegetation.
Quaternary sediments were deposited under the influence of waves and winds with enough power to suspend fine-grained sands and fine particles of the region. There are two sectors in dune field: an area where the sediment is exposed with notorious wind movement, and another colonized with vegetation (Dourado and Silva, 2005; Fernandez and Rocha, 2015).

Several authors, such as Martin et al. (1993), Castro et al. (2002, 2014), Castro (2006) and Dias et al. (2010), have suggested that the Pero dune field formation was related to paleoclimatic oscillations associated with sea level change prior to 5100 years BP. According to these authors, these conditions originated two lagoons, one internal and another external, isolated from the Atlantic Ocean by two barrier islands called "internal sandbank" and "external sandbank". Castro et al. (2006) recorded the presence of a coquine deposit found in Taua reserve, located at about $11 \mathrm{~km}$ to NW of Pero Beach, with an age ranging between $5034 \mathrm{cal} \mathrm{BP}$ and $5730 \mathrm{cal} \mathrm{BP}$. These authors emphasized that the transgressive maximum occurred around 5100 yrs BP, leading to the formation of a paleolagoon. During this event, there was a connection of the paleolagoon with the sea through a paleochannel located at the northeast end of the Pero Beach.

\section{Material and methods}

This study is based on the analysis of a core collected in the coastal plain of the Pero Beach, of Cabo Frio City, State of Rio de Janeiro (at latitude $22^{\circ} 50^{\prime} 15.93 " \mathrm{~S}$ and longitude $\left.41^{\circ} 59^{\prime} 11.41^{\prime \prime} \mathrm{W}\right)$, at about 2.41 meters above the current mean sea level. The core was recovered at 570 meters from the current coastline with the use of a vibracore.

The lithological and radiocarbon datings used in this work were obtained in earlier studies performed by Dias et al. $(2009,2010)$ and Castro et al. (2014).

\subsection{Granulometric analysis}

The granulometric analysis were performed in the Department of Geology (Sedimentology Laboratory), of the Universidade Federal do Rio de Janeiro (UFRJ), where the samples were washed, oven dried and sieved following the methodology described by Folk (1974).

\subsection{Total Organic Carbon analysis}

Samples were decarbonised and analyzed on a LECO WR-12 equipment, consisting of an induction furnace coupled to an infrared reader to determine the TOC values. 


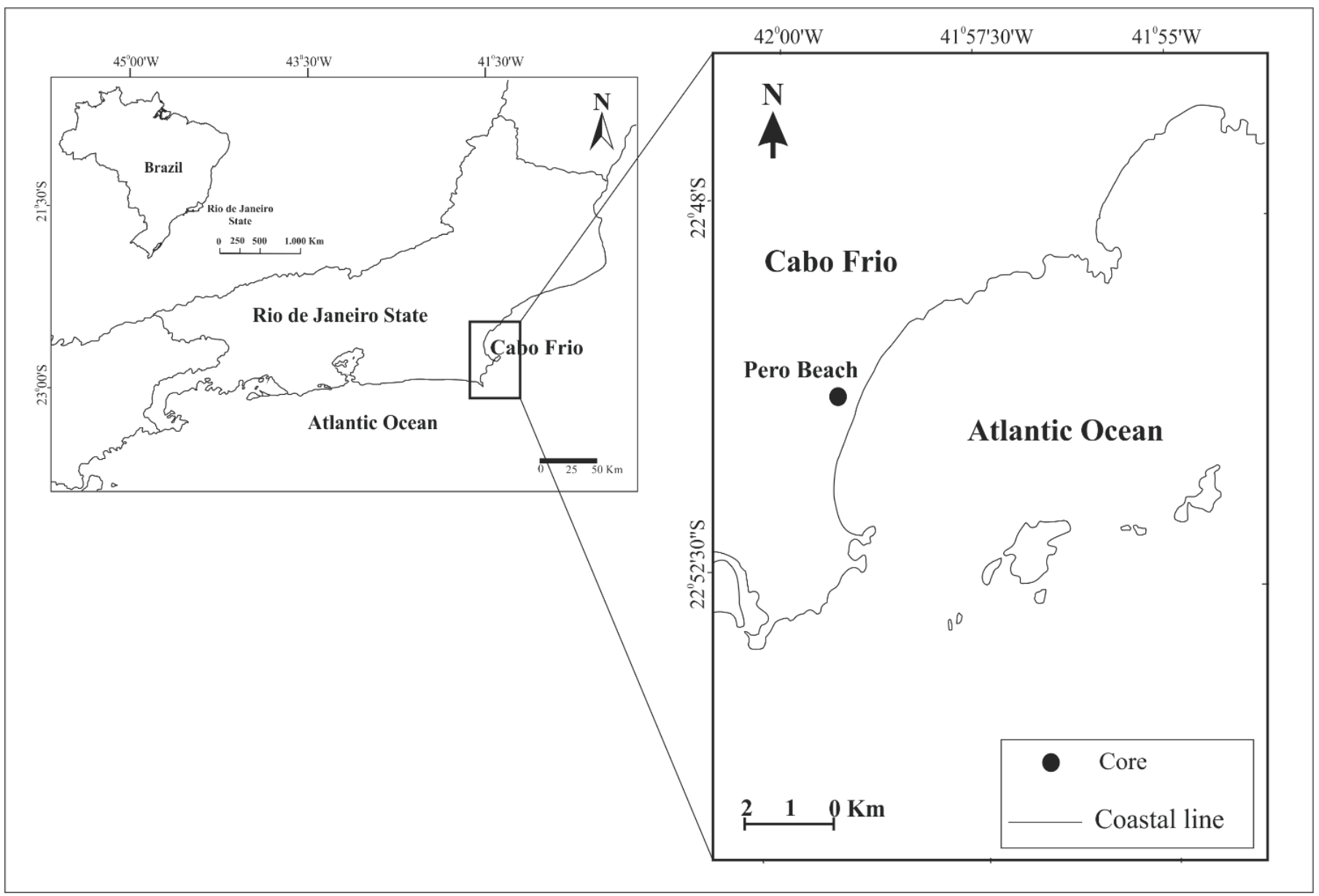

Fig. 1. Core localization at Pero Beach, Cabo Frio City - Rio de Janeiro state.

The TOC values are given in percentage by weight of organic carbon, which is based on a comparison with a reference standard.

\subsection{Preparation and analysis of palynofacies}

Preparation of material for analysis followed palynofacies non oxidative process protocol described by Tyson (1995) and Mendonça-Filho et al. (2002). This methodology consists of the acid etching of the material using hydrochloric and hydrofluoric acids for removal of carbonate and mineral fractions. Subsequently zinc chloride $\left(\mathrm{ZnCl}_{2}\right)$ was used in order to perform the separation and concentration of the organic matter.

The palynofacies analysis included qualitative and quantitative analysis of organic matter of three main groups:
Amorphous Organic Matter (AOM), Phytoclasts and Palynomorphs.

The classification of particulate organic matter was held with microscopy using transmitted white light and fluorescent radiation and with magnifications of $200 \mathrm{x}$ and 400x. The raw data obtained from the classification and counting of particles were transformed into percentage values for the groups and subgroups of organic matter.

\subsection{Radiocarbon datings}

The chronological analysis was obtained by radiocarbon dates $\left({ }^{14} \mathrm{C}\right)$ of samples taken from two stratigraphic levels: Anomalocardia brasiliana (Gaertn, 1807) (Combretaceae) shells and a carbonized trunk of Anomalocardia brasiliana (Gmelin, 1791) (Bivalvia, Veneridae), found in the core at $80 \mathrm{~cm}$ and $250 \mathrm{~cm}$ levels, respectively. The dates were held in the Head of Radiation Monitoring Hygienic Laboratory, located in 
Kiev, Ukraine. The ages were calibrated by Calib 4.1.2 software using the method SHCal04 for not marine samples and Marine04 option for marine samples.

\subsection{Statistical analysis}

The results were subjected to Q-mode cluster analysis, to observe similarities between samples, and R-mode to check similarity between organic components. For this purpose the Statistic Basic program, version 6.0 (Valentin, 2000) was used.

\section{Results}

\subsection{Core description}

The studied core is a sandy sequence composed mainly by fine sand varying from well selected to moderately selected sedimentary particles. In two stratigraphic levels have been identified biogenic materials: a carbonized trunk of the species L. racemosa, in the basal part of the core (250$240 \mathrm{~cm}$ ); and a level of mollusk shells, belonging mostly to the species $A$. brasiliana (at a depth of $80 \mathrm{~cm}$ ). Paleosol levels were also found in the core tope.

\subsection{Radiocarbon dating}

The results of radiocarbon dating levels were included in Tab. 1. An age of $6761 \pm 130 \mathrm{yrs}$ cal BP was estimated for the layer $250 \mathrm{~cm}$ and of $3187 \pm 186 \mathrm{yrs} \mathrm{cal} \mathrm{BP}$ for the layer $80 \mathrm{~cm}$. The model age based on the radiocarbon dates is presented in Fig. 2. Results of radiocarbon allows to estimate an accumulation rate of about $53.3 \mathrm{~cm} / 1000 \mathrm{yrs}$ for the core base $(250-80 \mathrm{~cm})$ and of about $39.8 \mathrm{~cm} / 1000 \mathrm{yrs}$ for the first $80 \mathrm{~cm}$ of the studied core. These results indicate a reduction in the sediments accumulation rate in the core top.

\subsection{Total Organic Carbon}

The sediments of the analyzed core have very low TOC content ranging from 0.08 to $0.03 \%$ (Tab. 2). However, it was possible to establish a ratio between the TOC content and opaque phytoclasts (Phy-TOC) ranging from 0.1 to $0.04 \%$. The description of the TOC and Phy-TOC ratio is detailed in the item 4.5.

\subsection{Palynofacies Analysis}

The results of palynomorphous analysis are included in Tab. 2 (examples in Plate 1). The studied core clearly shows a predominance of components of the Phytoclast Group. This group achieved an overall average of $73.2 \%$ of Particulate Organic Matter (POM), followed by the groups Amorphous Organic Matter $(18.6 \%)$ and Palynomorphs $(8.2 \%)$. The Phytoclast Group is dominated by particles of non-opaque components (non- biostructured and structured; $20.3 \%$ of POM). The second most abundant component is the opaque equidimensional phytoclast group, which reaches $19.3 \%$ of POM. This last component (opaque equidimensional phytoclasts) is often fragmented, reflecting an effective transport. The other components like membranes and cuticles are subordinated to the two most abundant components. In the Amorphous Organic Matter Group (AOM) the following components were recorded: $\mathrm{AOM}$, resin and pseudomorphs. The higher frequency is made by AOM mainly characterized by a light brown to dark colored material with aggregate palynomorphs.

In the Palynomorph Group, the terrestrial origin (spores, fungi, pollen and freshwater algae) are conspicuously more abundant than those of marine origin (microforaminiferal linings and dinoflagellate cysts). The curve for this group remains relatively uniform along the core. However, in the top core section a peak of palynomorphs of continental origin is recorded (e.g., spores and pollen). The dendrogram obtained by cluster analysis revealed five R-mode palynofacies (Fig. 3). The classification agrees with the highest degree of similarity of the components of organic matter in relation to the "origin criteria". Six depositional sections were obtained by Q-mode cluster analysis (Fig. 4) as the similarity between samples.

\subsection{Characterization of the sections defined by cluster analysis $Q$ mode (Fig. 4)}

The section $1(240-230 \mathrm{~cm}$, in torn of $6761 \pm 130 \mathrm{cal}$ years BP; Tab. 1) is characterized by the palynofacies 4 and 5 (Fig. 3), where the marine component (dinoflagellates and microforaminiferal linings) was found. In this section, the mean value of marine components is $2.8 \%$ of the total fraction of palynomorphs and of AOM with fluorescence is $27.1 \%$. The phytoclasts has the mean value of $70.1 \%$ of the total POM present in this section. In this section, the average value of TOC and Phy-TOC ratio is $0.06 \%$ and 0.04 respectively. 


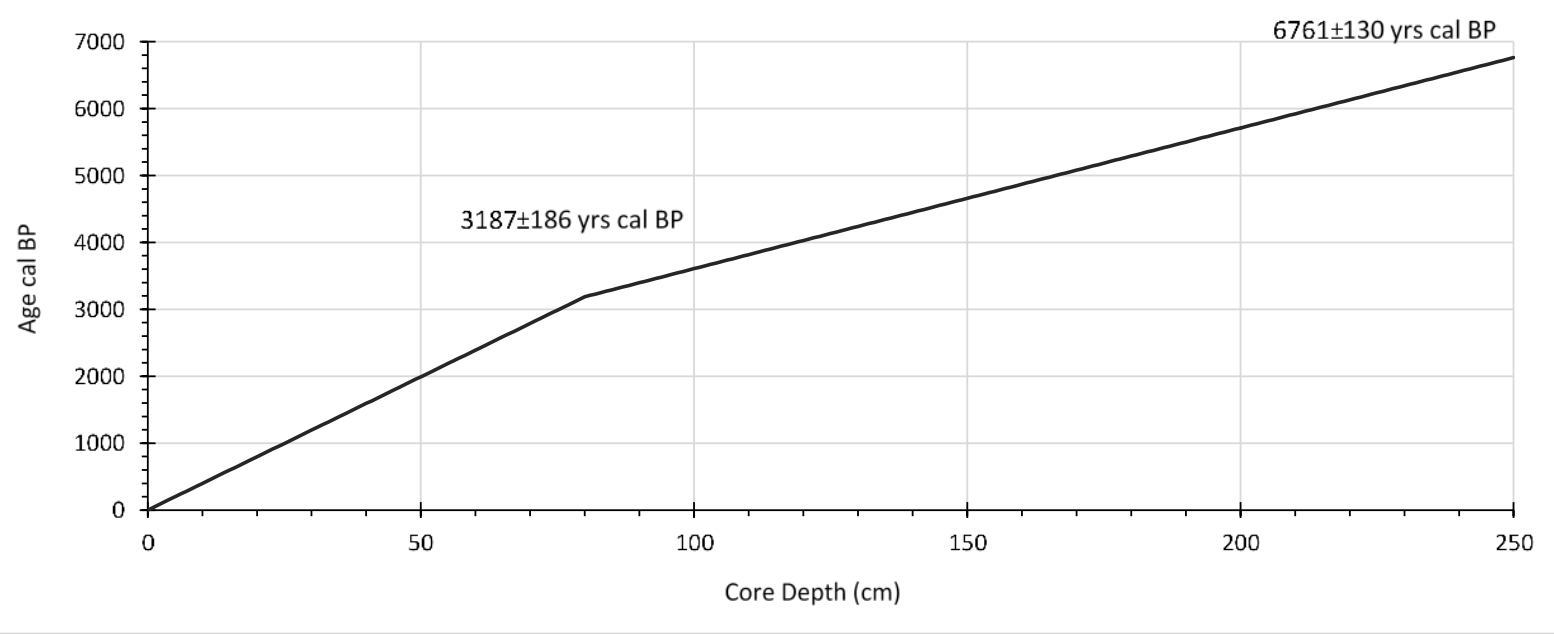

Fig. 2. Age model based on radiocarbon dates.

Tab. 1. Radiocarbon data obtained in the studied core.

\begin{tabular}{lccc}
\hline $\begin{array}{l}\text { Depth } \\
(\mathbf{c m})\end{array}$ & \multicolumn{1}{c}{$\begin{array}{c}\text { Analysed } \\
\text { Material }\end{array}$} & $\begin{array}{c}\text { Age } \\
\text { Years BP }\end{array}$ & $\begin{array}{c}\text { Calibrated } \\
\text { Age BP }\end{array}$ \\
\hline $\mathbf{2 5 0}$ & Charcoal (Laguncularia racemosa) & $5.910 \pm 55$ & $6.890-6.631$ \\
\hline $\mathbf{8 0}$ & Shells (Anomalocardia brasiliana) & $3.350 \pm 70$ & $3.373-3.000$ \\
\hline
\end{tabular}

Section 2 (230-170 cm; $\approx 6300-5000 \mathrm{yrs}$ cal BP) is marked by the presence of Palynofacies 5 , where the greater presence of $\operatorname{AOM}(35.2 \%)$ was found. Associated with the increased AOM component the smaller amount of phytoclasts (57.6\%) is found. In this section, the values of TOC and Phy-TOC is $0.03 \%$ and 0.02 , respectively.

Section $3(170-150 \mathrm{~cm} ; \approx 5000-4650$ yrs cal BP) is characterized by Palynofacies 4 . In this section, there is a significant fall of the amorphous organic matter $(7.1 \%)$, together with the considerable increase in phytoclasts $(87.2 \%)$ from the previous section. The presence of marine elements, represented by the occurrence of dinoflagellate cysts was observed. The average TOC content is $0.08 \%$. These values indicate that the highest TOC value of this section, is related to the increasing of the phytoclasts component. The value of Phy-TOC ratio (0.1) is the highest of this section.

In the Section 4 (150-125 cm; $\approx 4650-4130$ yrs cal BP), the remarkable presence of Palynofacies 3 was observed. In this section the Palynofacies 2 is an accessory assemblage (Fig. 3). In this interval, the smaller amount of AOM was recorded ( $3 \%$ of total organic matter). Else the AOM present in this interval showed no fluorescence. The phytoclasts reached the highest values of the studied core $(92.2 \%$ of POM; Fig. 4). Opaque equidimensional phytoclasts were the most representative assemblage, reaching $39.9 \%$ of POM. The continental palynomorph component showed an average of $4.8 \%$ of POM. The occasional presence of dinoflagellate cysts are observed in this section. The TOC content and Phy-TOC ratio mean values is $0.03 \%$ and 0.02 , respectively.

Section 5 (125-90 cm; $\approx 4130-4000$ yrs cal BP) records in general, a small decrease in the phytoclasts number in relation to the previous one $(80.9 \%)$. Among the phytoclasts, the dominance of opaque equidimensional particles is observed (Fig. 4).

The curve of AOM without fluorescence present a rising trend compared to the previous section. The average abundance of palynomorphs, with continental origin, is 7.5 $\%$ (spores of pollen grains). In this section, the mean TOC content and Phy-TOC ratio values is $0.03 \%$ and 0.02 , respectively (Fig. 4). 
Tab. 2: Results of the analysis of Particulate Organic Matter along the core collected in Pero Beach, Cabo Frio, Rio de Janeiro, Brazil. Radiocarbon calibrated ages and TOC content values are also presented.

\begin{tabular}{|c|c|c|c|c|c|c|c|c|c|c|c|c|c|c|c|c|c|c|c|c|c|c|}
\hline \multirow[b]{3}{*}{ 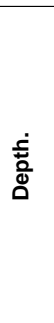 } & \multirow{3}{*}{ 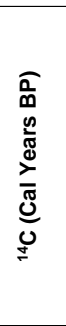 } & \multirow{2}{*}{\multicolumn{2}{|c|}{$\begin{array}{l}\text { Amorphous } \\
\text { group }\end{array}$}} & \multicolumn{11}{|c|}{ Phytoclast Group } & \multicolumn{6}{|c|}{$\begin{array}{l}\text { Palynomorphs } \\
\text { Group }\end{array}$} & \multirow[b]{3}{*}{ 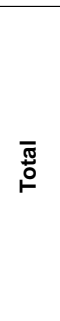 } & \multirow[b]{3}{*}{ 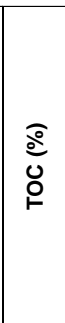 } \\
\hline & & & & \multicolumn{4}{|c|}{ Opaque Phytoclasts } & \multicolumn{7}{|c|}{ Non-Opaque Phytoclasts } & \multicolumn{4}{|c|}{ Terrestrial } & \multicolumn{2}{|c|}{ Marine } & & \\
\hline & & ๖ั & $\begin{array}{l}\frac{c}{\bar{g}} \\
\widetilde{x}\end{array}$ & $\begin{array}{l}\frac{0}{5} \\
\frac{0}{0}\end{array}$ & 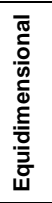 & 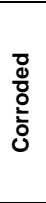 & 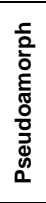 & 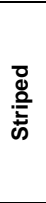 & 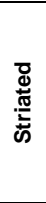 & 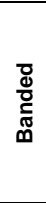 & 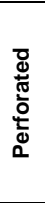 & 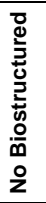 & 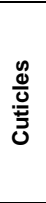 & 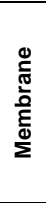 & के & 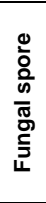 & $\frac{5}{0}$ & 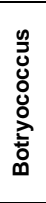 & 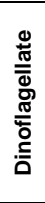 & 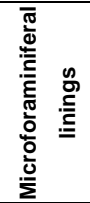 & & \\
\hline 75 & 3372 & 2 & 3 & 30 & 31 & 44 & 6 & 18 & 1 & 0 & 4 & 17 & 15 & 16 & 40 & 42 & 25 & 6 & 0 & 0 & 295 & 0.00 \\
\hline 85 & & 15 & 1 & 9 & 15 & 53 & 3 & 10 & 1 & 8 & 8 & 21 & 24 & 19 & 31 & 40 & 20 & 22 & 0 & 0 & 284 & 0.00 \\
\hline 90 & & 21 & 8 & 12 & 134 & 0 & 0 & 2 & 5 & 5 & 5 & 25 & 20 & 14 & 27 & 0 & 3 & 0 & 0 & 0 & 252 & 0.00 \\
\hline 95 & & 33 & 0 & 30 & 70 & 46 & 10 & 4 & 7 & 8 & 3 & 6 & 12 & 43 & 21 & 7 & 0 & 0 & 0 & 0 & 267 & 0.00 \\
\hline 100 & & 38 & 4 & 18 & 156 & 0 & 0 & 6 & 3 & 6 & 5 & 20 & 8 & 16 & 14 & 0 & 6 & 0 & 0 & 0 & 258 & 0.00 \\
\hline 105 & & 9 & 3 & 22 & 91 & 0 & 0 & 7 & 8 & 13 & 4 & 19 & 6 & 14 & 5 & 1 & 0 & 0 & 0 & 0 & 190 & 0.02 \\
\hline 110 & & 22 & 0 & 40 & 91 & 58 & 6 & 8 & 9 & 1 & 9 & 6 & 12 & 26 & 11 & 0 & 1 & 0 & 0 & 0 & 278 & 0.05 \\
\hline 115 & & 5 & 1 & 4 & 6 & 0 & 0 & 1 & 0 & 1 & 0 & 6 & 0 & 1 & 2 & 0 & 1 & 0 & 0 & 0 & 22 & 0.04 \\
\hline 125 & & 16 & 1 & 26 & 54 & 50 & 8 & 6 & 8 & 19 & 12 & 27 & 5 & 20 & 13 & 2 & 4 & 0 & 0 & 0 & 254 & 0.02 \\
\hline 130 & & 10 & 3 & 44 & 155 & 0 & 0 & 8 & 8 & 10 & 8 & 14 & 17 & 18 & 0 & 0 & 0 & 0 & 0 & 0 & 282 & 0.05 \\
\hline 135 & & 4 & 0 & 41 & 182 & 0 & 0 & 3 & 11 & 13 & 1 & 8 & 10 & 15 & 11 & 0 & 1 & 0 & 0 & 0 & 296 & 0.03 \\
\hline 140 & & 0 & 0 & 41 & 80 & 65 & 8 & 15 & 10 & 13 & 17 & 4 & 7 & 16 & 14 & 0 & 10 & 0 & 1 & 0 & 301 & 0.05 \\
\hline 150 & & 7 & 0 & 38 & 90 & 0 & 0 & 6 & 28 & 13 & 3 & 18 & 49 & 35 & 13 & 0 & 0 & 0 & 1 & 0 & 294 & 0.07 \\
\hline 155 & & 23 & 0 & 19 & 29 & 14 & 2 & 8 & 20 & 21 & 3 & 17 & 29 & 83 & 21 & 10 & 1 & 0 & 2 & 0 & 279 & 0.07 \\
\hline 160 & & 8 & 0 & 4 & 25 & 1 & 0 & 6 & 11 & 18 & 5 & 76 & 54 & 85 & 2 & 0 & 5 & 0 & 0 & 0 & 292 & 0.10 \\
\hline 165 & & 47 & 0 & 6 & 47 & 0 & 0 & 0 & 16 & 18 & 2 & 36 & 67 & 48 & 9 & 0 & 3 & 0 & 0 & 1 & 253 & 0.07 \\
\hline 170 & & 21 & 1 & 4 & 12 & 13 & 14 & 24 & 13 & 44 & 4 & 20 & 54 & 59 & 16 & 1 & 0 & 0 & 0 & 0 & 278 & 0.00 \\
\hline 175 & & 12 & 0 & 3 & 30 & 7 & 0 & 0 & 2 & 6 & 2 & 16 & 26 & 22 & 5 & 1 & 1 & 0 & 0 & 0 & 121 & 0.05 \\
\hline 180 & & 129 & 2 & 15 & 45 & 1 & 1 & 0 & 5 & 6 & 0 & 15 & 9 & 50 & 10 & 12 & 0 & 0 & 0 & 0 & 169 & 0.00 \\
\hline 185 & & 150 & 0 & 9 & 16 & 30 & 14 & 10 & 0 & 8 & 0 & 11 & 14 & 18 & & 14 & 6 & 0 & 0 & 0 & 150 & 0.03 \\
\hline 195 & & 51 & 1 & 14 & 29 & 1 & & 9 & 17 & 8 & 5 & 13 & 11 & 31 & 9 & 6 & 2 & 0 & 0 & 0 & 155 & 0.04 \\
\hline 200 & & 79 & 2 & 6 & 18 & 22 & 12 & 18 & 7 & 14 & 1 & 30 & 44 & 26 & 11 & 1 & 8 & 0 & 0 & 1 & 219 & 0.05 \\
\hline 205 & & 4 & 0 & 0 & 0 & 0 & 0 & 1 & 1 & 0 & 0 & 0 & 0 & 4 & 1 & 0 & 0 & 0 & 0 & 0 & 7 & 0.05 \\
\hline 210 & & 31 & 0 & 4 & 14 & 15 & 2 & 0 & 0 & 1 & 0 & 0 & 5 & 8 & 8 & 1 & 0 & 0 & 0 & 0 & 59 & 0.04 \\
\hline 215 & & 109 & 1 & 14 & 42 & 3 & 0 & 21 & 3 & 8 & 8 & 12 & 21 & 40 & 18 & 0 & 0 & 0 & 0 & 0 & 190 & 0.05 \\
\hline 220 & & 157 & 5 & 18 & 27 & 0 & 0 & 1 & 6 & 6 & 2 & 9 & 20 & 41 & 7 & 0 & 1 & 0 & 0 & 0 & 138 & 0.03 \\
\hline 225 & & 107 & 0 & 10 & 15 & 25 & 6 & 20 & 17 & 9 & 6 & 20 & 20 & 21 & 15 & 0 & 4 & 0 & 0 & 0 & 193 & 0.00 \\
\hline 230 & & 74 & 0 & 8 & 11 & 3 & 0 & 24 & 22 & 26 & 8 & 27 & 62 & 33 & 2 & 0 & 0 & 0 & 0 & 0 & 226 & 0.03 \\
\hline 235 & & 40 & 0 & 15 & 19 & 3 & 4 & 23 & 27 & 43 & 6 & 23 & 30 & 53 & 14 & 0 & 0 & 0 & 0 & 0 & 260 & 0.05 \\
\hline 240 & 6361 & 132 & 0 & 2 & 2 & 7 & 0 & 22 & 19 & 12 & 5 & 25 & 41 & 28 & 2 & 2 & 0 & 1 & 3 & 1 & 172 & 0.10 \\
\hline
\end{tabular}

Section 6 (90-75 cm; $\approx 4000-3000$ yrs cal BP) is characterized by the ocorrence of Palynofacies 1 . It is composed mostly by continental palynomorphs $(37.7 \%$ of POM; Fig. 4). The continental palynomorph component, such as spores and pollen grains, reach $25.5 \%$ and $7.5 \%$ of
POM, respectively. The continental nature is also confirmed by the presence of the algae Botryococcus braunii (Kützing, 1849) representing $4.7 \%$ of the palynomorphs. The Palynofacies 2 is characterized by the strong presence of corroded elements that may indicate effective transport of 
organic material. In this section, it was not possible to obtain results of TOC (and Phy-TOC ratio) due to the too much low percentage of organic matter.

The sediments were reworked in the first $75 \mathrm{~cm}$ of the studied core. So the samples of this section were not considered.

\section{Discussion}

\subsection{Total Organic Carbon}

The values of TOC and Phy-TOC ratio are low throughout the studied core when compared to other studies conducted in other coastal regions of Brazil (Zocatelli et al., 2012; Boussafir et al., 2012; Lorente et al., 2014; GadensMarcon et al., 2014a). However, Amaral et al. (2012) analyzed three coastal cores, collected in the State of Santa Catarina, also observing low TOC values. In this work, we can associate the low values of TOC, absence of amorphous organic matter (or low frequency) and high occurrence of opaque equidimensional phytoclasts, to the sediments grain size, which indicate a high-energy environment.

\subsection{Palynofacies Analysis}

The strong presence of marine elements (mainly the dinoflagellate's cysts), at about $6761 \pm 130 \mathrm{yrs}$ cal BP in the studied core indicates that the Pero Beach region was influenced by marine water at that time. According to some authors (e.g. Suguio et al., 1985; Martin et al., 1997; Angulo and Lessa, 1997) the middle Holocene sea level was 4 meters above the current (Transgressive event). This event possibly contributed to the deposition of marine palynomorphs. According to Castro et al. (2014) and Dias et al. (2010), this record may be associated with beach ridges which should have isolated and formed a paleolagoon in Pero Beach region due to the relative rise of sea level. Further evidence of higher sea level was suggested by Scheel-Ybert (2000). This author found mangrove records on the banks of Itajuru Canal, Cabo Frio, which were established during the highest Holocene sea level. The same situation was observed at about 7000 - 6000 yrs. BP in several zones along the Brazilian coast.

The presence of marine elements associated with the amorphous organic matter in a quantity greater than the mean for the studied core (Fig. 4), suggests a slight confinement of the study area, which would allow their preservation. However, terrigenous inputs are pronounced in this environment with continental palynomorphs (pollens and spores).

The marine influence was most evident at about 6300 5000 yrs cal BP in the studied site (Section 2), associated with a greater presence of AOM (Palynofacies 5) and a lower frequency of non-opaque phytoclasts that is interpreted as a greater distance and / or lower terrigenous input in the paleolagoon (Tyson, 1995; Menezes et al., 2008; Silva et al., 2010). In the sea level curve proposed by Castro et al. (2014) the sea level was rising steadily.

Similarly to the previous section, the paleoenvironment in the studied site was probably characterized by the presence of a paleolagoon associated with mangrove vegetation, but with less influence of continental elements (Fig. 4). The significant decrease of the amorphous organic matter (AOM) since $\approx 5000$ yrs cal BP, suggests that its preservation was hampered by strong terrigenous contribution in the lagoon (Palynofacies 4) indicating the start of the lagoon desiccation process (Section 3). In this period, the high values of TOC and Phy-TOC indicated possible proximity to the source area. In addition, the conspicuous presence of non-opaque phytoclasts allows us to suggest that at that time began a greater continental influence. The occurrence of non-opaque phytoclasts was observed by Boussafir et al. (2012) in a pond located in the Northeast of Brazil. According to this author, the presence of this type of phytoclasts could indicate a long exposure to subaerial environment or remobilization of organic matter from the soil or rocks. Lorente et al. (2014) analyzing sediments of a lake in southeastern Brazil highlighted the occurrence of non-opaque phytoclasts and correlated them to a greater continental input driven by fluvial influence.

The continental influence was becoming increasingly evident from 4650 yrs cal BP (sections 4 and 5). This is suggested mainly by the high frequency of non-opaque phytoclasts in relation to the declining of the AOM values, and the strong presence of continental palynomorphs (pollen and spores). The phytoclasts present high frequency at about 4130 yrs cal BP (Section 5), along with a small decrease of the AOM without fluorescence and plenty of continental palynomorphs. According to some authors, the beginning of a drying of the entire lagoon complex in the region occurred in this period, in coincidence with the replacing of the lagoon areas by wetlands (Suguio et al., 1985; Martin et al., 1997; Castro et al., 2014). Castro et al. (2014) noted the beginning of a decline in sea level in the region at that time. 


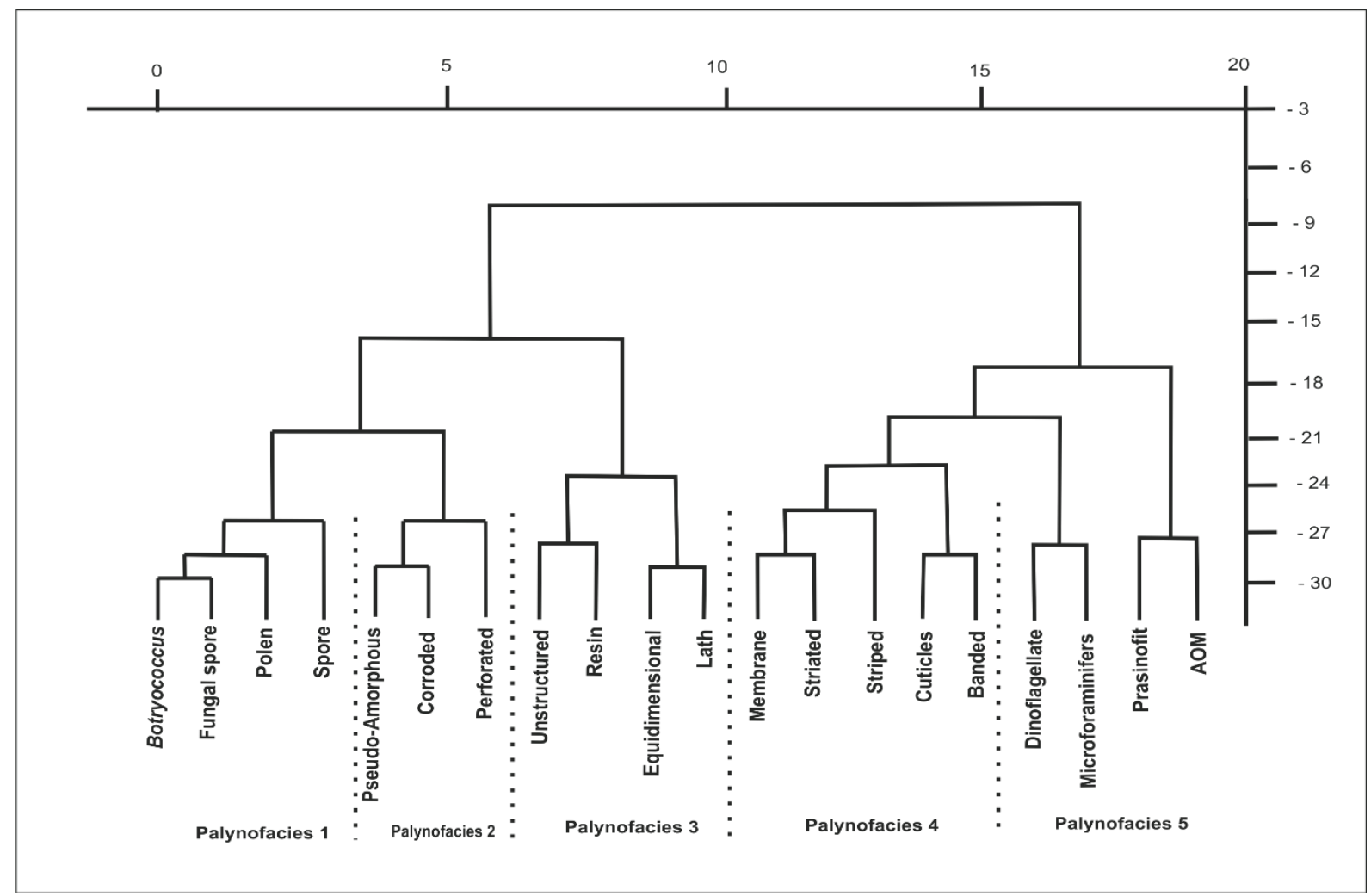

Fig. 3. Dendrogram (R-Mode cluster anlysis) for the groups and subgroups of organic matter components.

The total silting of the lagoon and the transformation of its surrounding region in wet areas should have occurred at about 3373 yrs cal BP (Section 6). This may be indicated by a strong presence of strictly continental palynomorphs (Palynofacies 1).

The continental influence was also confirmed by the presence of Botryococcus bramii algae. It should be noted that the occurrence of corroded elements in Palynofacies 2 indicate effective transport (Fig. 4).

These results suggest that this period may be interpreted as a high energy environment with low AOM preservation and small abundance of opaque phytoclasts. These characteristics may indicate a higher fluvial distance, an exposed area of sediment to oxidative processes or reworking by transport agents.

\section{Conclusion}

This study provides important palynofacies data for paleoenvironmental reconstruction of the coastal plain of
Pero Beach. Particulate organic matter from sediments presented characteristics in its abundance, color and structures that might be associated with environmental changes in the study area.

In the period between $6761-5000 \mathrm{yrs}$ cal BP, the sand bar of the study area was under strong influence of marine waters due to the Holocene Transgressive Event, evidenced by the abundance of dinoflagellate cysts. After this period, the records suggested a progressive increase of the continental influence, based on high frequency of nonopaque phytoclasts indicated by the decreasing of the AOM values, and by the high presence of continental palynomorphs (pollen and spores).

Since 3373 yrs cal BP, the high presence of strictly continental palynomorphs indicated the probable silting of the lagoon and signed the evolution for the present situation.

Thus, the application of the palynofacies study the coastal sediments is a valuable method for paleoenvironmental and paleoclimatic reconstruction, contributing to a better understanding of the evolution of coastal environments. 


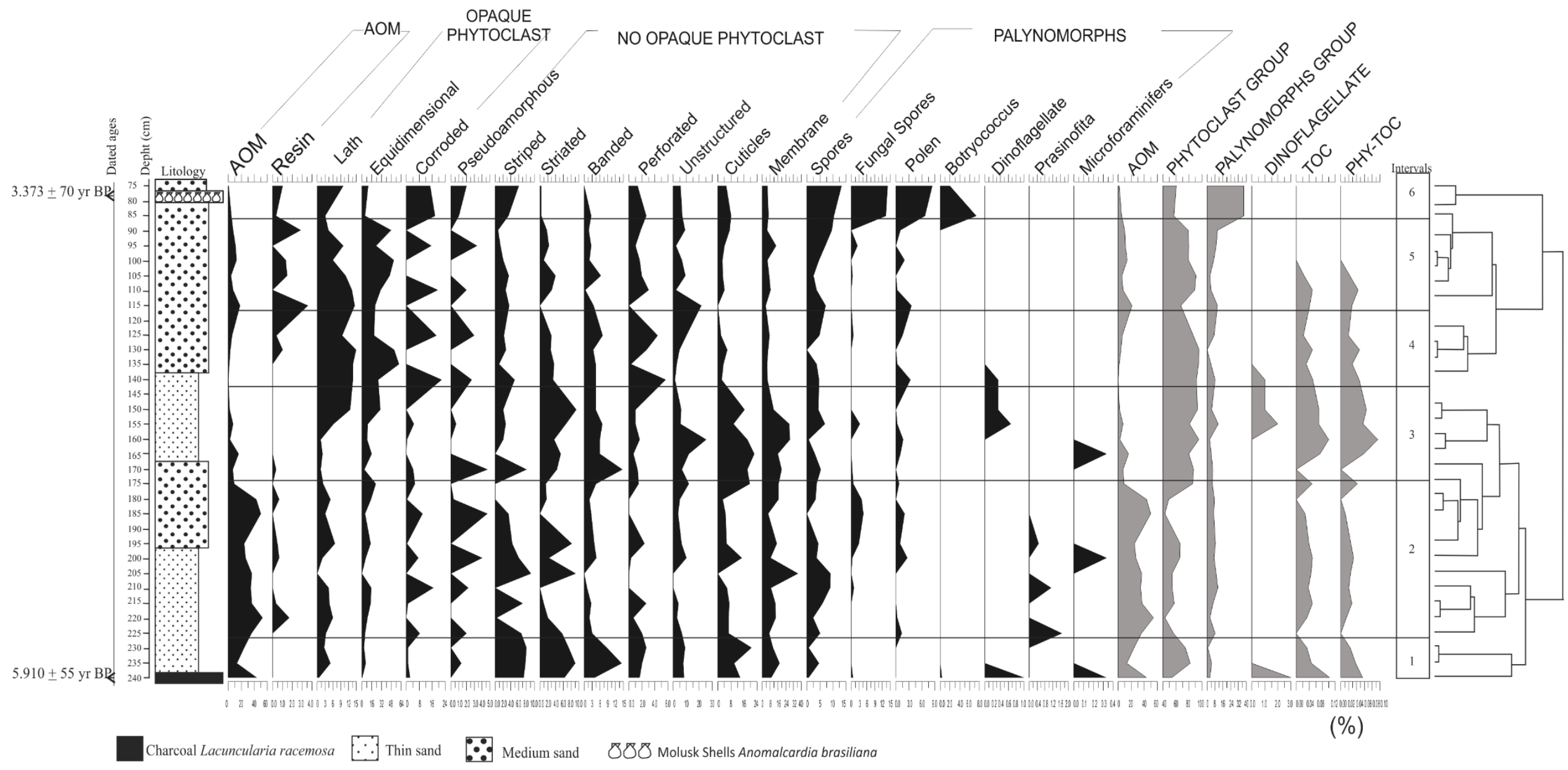

Fig. 4. Dispersion peak of particulate organic matter throughout the core. Gray peaks of large groups of organic matter, highlighting the dinoflagellates peaks. Percentage TOC and TOC-Phy ratio. Dendrogram R-mode presenting association samples throughout the core. 

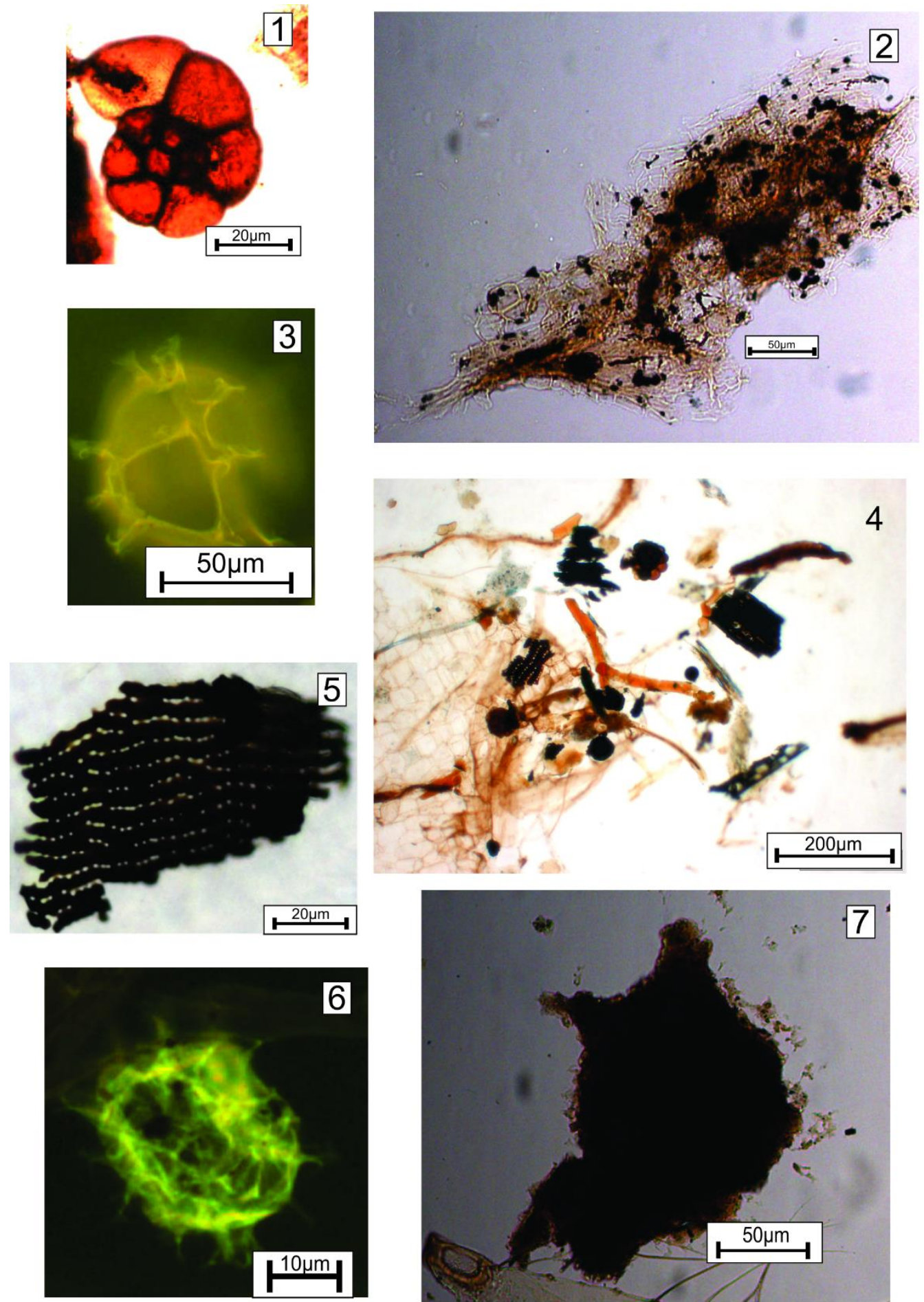

Plate 1 - Photomicrographs of the Particulate Organic Matter found along the studied core: 1. Microforaminifera; 2. Cuticle; 3. Spiniferites delicatus; 4. Association of opaque phytoclasts and non-opaque phytoclasts, microforaminifera and pollen; 5 . Perforated phytoclast nonopaque; 6. Spiniferites sp.; 7. Amorphous organic matter. 


\section{Acknowledgments}

The authors would like to thank to the Editor in Chef and the reviewers of the Journal of Sedimentary Environments which significantly contributed to this work improvement and to CAPES and CNPq for student's fellowships.

\section{References}

Amaral, P.G.C., Giannini, P.C.F., Sylvestre, F., Pessenda, L.C.R., 2012. Paleoenvironmental reconstruction of the Late Quaternary lagoon system in southern Brazil (Jaguaruna region, Santa Catarina state) based on multi-proxy analysis. Journal of Quaternary Science 27 (2), 181-191.

Angulo, R.J., Lessa, G. 1997. The Brazilian sea level curves: a critical review with emphasis on the curves from Paranaguá and Cananéia regions. Marine Geology 140, 141-166.

Boussafir, M., Sifeddine, A., Jacob, J., Foudi, M., Cordeiro, R.C., Albuquerque, A.L.S., Abrao, J.J., Turcq, B., 2012. Petrographical and geochemical study of modern lacustrine sedimentary organic matter (Lagoa do Caçó, Maranhão, Brazil): relationship between early diagenesis, organic sedimentation and lacustrine filling. Organic Geochemistry 47, 88-98.

Castro, J.W.A., Suguio, K., Seoane, J.C.S., Cunha, A.M. Dias, F.F. 2014. Sea-level fluctuations and coastal evolution in the state of Rio de Janeiro, southeastern Brazil. Anais da Academia Brasileira de Ciências 86 (2), 671-683.

Castro, J.W.A., 2006. Dunas da praia do Peró - APA Pau Brasil Cabo Frio / RJ: movimentação de sedimentos eólicos e problemas de soterramentos. XLIII Congresso Brasileiro de Geologia, Resumos Expandidos. Aracaju. UFBA, 1, 24-25.

Castro, J.W.A., Senra, M.C.E., Ramos, R.R.C., 2006. Coquinas da Paleolaguna da Reserva Tauá - Pântano da Malhada, RJ, um registro do optimum climático holocênico. In: Winge, M., Schobbenhaus, C., Berbert-Born, M., Queiroz, E.T., Campos, D.A., Souza, C.R.G., Fernandes, A.C.S. (Eds.), Sítios Geológicos e Paleontológicos do Brasil. URL: http://www.unb.br/ig/sigep/sitio004/sitio004.pdf. Access $13 / 09 / 2015$.

Castro, J.W.A., Ávila, C.A., 2002. Sistema de dunas obliquas do litoral de Cabo Frio - Estado do Rio de Janeiro. In: IV Simpósio Nacional de Geomorfologia, 2002, São Luiz. Boletim de Resumos do IV Simpósio Nacional de Geomorfologia. São Luiz: Sociedade Brasileira de Geomorfologia, 72-72.

Dias, F.F., Castro, J.W.A., Seoane, J.C.S., 2010. Dinâmica Sedimentar da Praia do Peró - Cabo Frio/ RJ - Nos últimos 7000 anos: Análise Pretérita e Atual. Revista Brasileira de Cartografia 62 (02), 145-154.

Dias, F.F., Seoane, J.C., Castro, J.W.A., 2009. Evolução da Linha de Praia do Peró, Cabo Frio / RJ nos Últimos 7.000 Anos. Anuário do Instituto de Geociências 32 (1), 9-20.
Dourado, F.A., Silva, A.S., 2005. Monitoramento do avanço de frente de dunas na região do Peró, Cabo Frio, Rio de Janeiro. Anais do XII Simpósio Brasileiro de Sensoriamento Remoto, Goiânia, Brasil, 2957-2964.

Fernandez, G.B., Rocha, T.B., 2015. Barreiras costeiras Holocênicas: geomorfologia e arquitetura deposicional no litoral do Rio de Janeiro. Revista Brasileira de Geomorfologia 16 (2), 301-319.

Folk, R.L., 1974. The petrology of sedimentary rocks. Austin, Texas, Hemphill Publishing Co, 182.

Gadens-Marcon, G.T., Mendonça-Filho, J.G., Guerra Sommer, M., Carvalho, M.A., Pires, E.F., Hartmann, L.A., 2014a. Relation between the sedimentary organic record and the climatic oscillations in the Holocene attested by palynofacies and organic geochemical analyses from a pond of altitude in southern Brazil. Anais da Academia Brasileira de Ciências 83 (3), 1077-1099.

Gadens-Marcon, G.T., Guerra-Sommer, M., Mendonça -Filho, J.G., 2014b. Palynofacies and organic geochemistry studies of organic matter from a wetland system of southern Brazil influenced by different hydrological regimes in the Quaternary. Journal of South American Earth Sciences 56, 41-53.

Hermany, G., Souza, P.A., Torgan, L.C., 2013. Paleoecologia do sistema Pinguela-Palmital-Malvas, Holoceno da Bacia de Pelotas, RS, Brasil: uma abordagem focada na utilização de análises multivariadas para obtenção de diatomáceas descritoras Pesquisas em Geociências 40 (1), 31-49.

Lorente, F.L., Pessenda, L.C.R., Oboh-Ikuenobe, F., Buso Jr, A.A., Cohen, M.C.L., Meyer, K.E.B., Giannini, P.C.F., Oliveira, P.E., Rossetti, D.F., Borotti Filho, M.A., França, M.C., Castro, D.F., Bendassolli, J.A., Macario, K., 2014. Palynofacies and s'Tab. C and $\mathrm{N}$ isotopes of Holocene sediments from Lake Macuco (Linhares, Espírito Santo, southeastern Brazil): Depositional settings and palaeoenvironmental evolution. Palaeogeography, Palaeoclimatology, Palaeoecology 415, 69-82.

Martin, L., Suguio, K., Dominguez, J.M.L., 1997. Geologia do Quaternário Costeiro do Litoral Norte do Rio de Janeiro e do Espírito Santo. Companhia de Pesquisa de Recursos Minerais (CPRM), São Paulo, 112 p.

Martin, L., Turcq, B., Flexor, J.M., Suguio, K., 1993. Evolução da planície costeira entre Guaratiba e Cabo Frio (RJ). IV Congresso da Associação Brasileira de Estudos do Quaternário - ABEQUA. São Paulo.

Medeanic, S., Silva, M.B., 2010. Indicative value of non-pollen palynomorphs (NPPs) and palynofacies for palaeoreconstructions: Holocene Peat, Brazil. International Journal of Coal Geology 84, 248-257. doi.org/10.1016/j.coal.2010.08.015

Mendonça-Filho, J. G., Carvalho, M. A., Menenzes, T. R. 2002. Palinofácies. In: Técnicas e procedimentos de trabalho com fósseis e formas modernas comparativas. Unisinos Ed. São Leopoldo, 20-24. 
Menezes, T.R., Mendonça-Filho, J.G., Araujo, C.V., Souza, I.V.A.F., Mendonça, J.O., 2008. Fácies Orgânica: conceitos e estudos de casos na indústria do petróleo. Revista Brasileira de Geociências 38 (2), 80-96.

Meyer, K.E.B., Büchi, A., Karfunkel, J., Hofmann, M., Hoppe, A., 2010. Palinofácies e evolução quaternária do Ribeirão da Mata, Município de Vespasiano, MG, Brasil. Revista Brasileira de Paleontologia, 13 (1), 41 -48.

Meyer, K.E.B., Mendonça Filho, J.G., Ashraf, A.R., Souza, P.A., Reichhart, K., 2005. Análise de Palinofácies em Sedimentos Holocênicos da Lagoa dos Quadros, Rio Grande do Sul, Brasil. Revista Brasileira de Paleontologia 8 (1), 57-72.

Scheel-Ybert, R., 2000. Vegetation stability in the Southeastern Brazilian costal area from 5500 to $140014 \mathrm{C}$ yr BP deduced from charcoal analysis. Review of Paleobotany and palynology 110, 111-138.

Silva, Y.M.P., Meyer, K.E.B., Perônico, C., Castro, P.T.A., 2010. Palinofácies de uma sequência sedimentar quaternária da Lagoa Preta, Parque Estadual do Rio Doce, MG, Brasil. Revista Brasileira de Paleontologia 13 (1), 49-56.
Suguio K., Martin, L., Bittencourt, A.C.S.P., Dominguez, J.M.L., Flexor, J.M., Azevedo, A.E.G., 1985. Flutuações do nível relativo do mar durante o Quaternário superior ao longo do litoral brasileiro e suas implicações na sedimentação costeira. Revista Brasileira de Geociências 15 (4), 273-286.

Traverse, A., 2008. Paleopalynology Second Edition. Springer, Netherlands.

Traverse, A., 1994. Sedimentation of palynomorphs and palynodebris: an introduction. In: A. Traverse (ed.) Sedimentation of Organic Particles. Cambridge University Press, 1-8.

Tyson, R.V., 1995. Sedimentary Organic Matter: Organic facies and palynofacies. Chapman and Hall. $1^{\mathrm{a}}$ edition. London.

Valentin, J.L., 2000. Ecologia Numérica. Interciência, Rio de Janeiro.

Zocatelli, R., Bernardes, M., Turcq, B., Albuquerque, A. L., Siffedine, A., Jacob, J., Boussafir, M., 2012. Composição da matéria orgânica lacustre como ferrementa na reconstrução paleoambiental na Lagoa do Caçó, Maranhão, Brasil. Geochimica Brasiliensis, Ouro Preto, 26 (1), 67-78 